\title{
"The Adventurer of the Desert" Prince Kamal Eldin Hussein
}

\author{
By Enas Fares Yehia*
}

Prince Kamal Eldin Hussein was the son of Sultan Hussein Kamel. He was the heir presumptive, but he refused to rule in a unique case in the history of modern Egypt. There were many opinions concerning this matter, and it was kept secret in Egyptian history. This article discusses the role of the Prince in Egyptian life, and how he was close to the Egyptians. He was fond of exploring the desert, and made many important excavations there, so he deserves the Egyptian Tourism Ministry's interest in his excavations since it celebrates the anniversary of the exploration of the Gilf Kebir area by arranging a journey every year to his plaque there. In the Hollywood film "The English Patient", the main character was transporting Prince Kamal Eldin's plaque to the Gilf Kebir Plateau in 1933. Since the release of this film the area has witnessed increased interest from tourists, scientists and historians.

\section{The Life of the Prince}

Prince Kamal Eldin Hussein was the son of Sultan Hussein Kamel from his wife princess Ain Al Hayat the daughter of prince Ahmed Refat. He was born in 1875, and was educated at the Theresia Military Academy in Austria. He attained the rank of general, and became commander in chief of the Egyptian army. On 5 May 1904 he married Princess Nimat Allah the younger daughter of Khedive Tewfik, but he had no children with her, although she had a son from her previous husband, Adel Toson. ${ }^{1}$

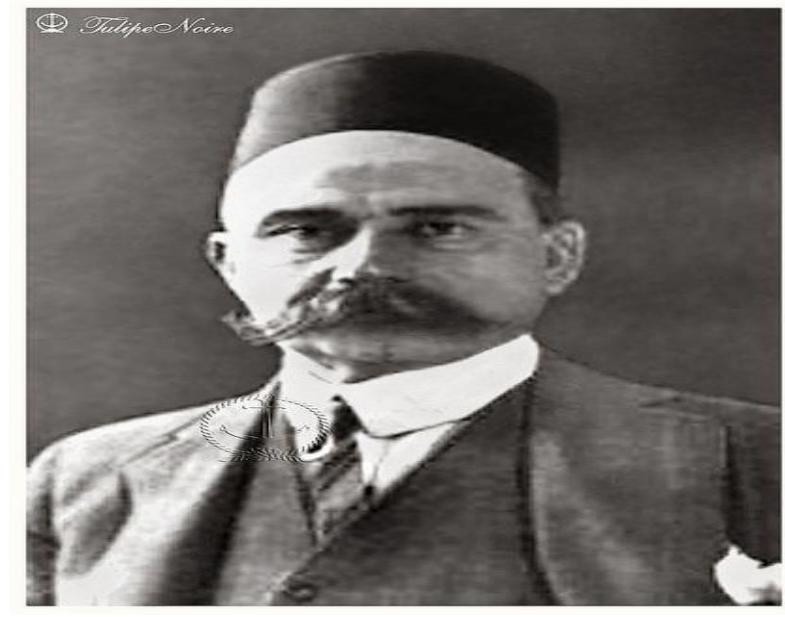

Figure 1. Prince Kamal Eldin Hussein

* Lecturer of Modern and Contemporary History, Faculty of Tourism and Hotels, Minia University, Egypt.

1. Kh. El. Al Zeralkey, Qamws Al Trajem wa Al Alam [Dictionary of the Famous C.V.s ], vol.5, 5th ed. (Beirut: Dar Elealm Llmalaeen, 2002), 233. 
Source: http://bit.ly/2eBNy6f.

His character was kind, cooperative and helpful. ${ }^{2}$ He rejected any appearance in crowded communities as he was very shy, and as a result of his character he prevented journalists from publishing any news concerning his life or movements. This meant that little reached the public about his life, and they searched for him between lines, even though he was an important member of the royal family. He lived away from palace life, as he preferred to be aside from it. Although he was modest, he cared about protocol; on one occasion he returned a ticket to a charity because they sent it by mail, and they did not give it to him by hand. When they discovered their fault they went to him and he accepted their invitation and donated 10 pounds to them. ${ }^{3}$ The Egyptians loved him because of his charitable actions. In fact, the Prince neglected the palace life and his only concern was practicing his favourite hobby, exploring the desert. He was a great sportsman. He loved horsemanship and his great love for hunting led him into Egypt's deserts. He began to explore the Western Desert in 1923.

With the outbreak of World War I in 1914, Egypt became a major base for the Allies, and on 18 December 1914 Great Britain declared a protectorate over Egypt. The British legalized Egypt's occupation to be sure that they would not side with the Ottoman Empire or Germany. A high commissioner was placed at the head instead of the British Consul General who was listed as a diplomatic representative. ${ }^{4}$ Prince Kamal Eldin Hussein was in Europe, with many princes who left Egypt because of the war situation and the British control of the palace. Many of them preferred to stay in Europe, but Prince Kamal Eldin Hussein returned to Egypt after the British acceptance of Sultan Hussein Kamal's demand for the return of his son. ${ }^{5}$ In December 1914 his father Hussein Kamel was declared Sultan by the British replacing Abbas Hilmi II, who had been exiled for his German sympathies.

After the return of Prince Kamal Eldin Hussein to Egypt, and under British pressure, he led the IPO Committees which were formed on 26 October 1916, which aimed to build charitable institutions aiming to glorify Kitchener's name, so the Prince was invited to IPO for this reason. ${ }^{6} \mathrm{He}$ accepted the invitation not to satisfy the British, but because he was famous for his charitable actions, which was why he was chosen by the British for the matter.

Concerning his role in the Egyptian economy, the Prince led the Agriculture Assembly after his father Sultan Hussein Kamel, from 20 April

2. Z. Fahmi, Safwat Alaser fi Tareikh wa Rswoom Mashaheer Rejal Masr [The Chosen from the Famous From Egypt] (Cairo: Hendawi Institution for Education and Culture, 2013), 105.

3. Almswar Newspaper, Feb. 1933, issue 409, 3.

4. D. B. Rosten, The Last Cheetah of Egypt: A Narrative History of Egyptian Royalty from 1805 to 1953 (, Bloomington: iUniverse Press, 2015), 112.

5. Al Moaed Newspaper, Feb. 1915, issue 9876, 27.

6. A. E. Ramadan, Mozkrat Saad Zagloul [Saad Zagloul Personal Notes], vol 6, from 13 September 1916 to 15 November 1917 (Cairo: Marcaz Wathaeq waTarekh Masr El Moaser, 1993), 25. 
1915. ${ }^{7}$ After the British occupation, Cromer transformed Egypt from a polycrop country to mono-crop country, which was cotton. This affected the land greatly, so Egypt was in great need of the founding of an assembly to manage agriculture. The British supported the idea and they reopened it in 1898 under the name of the Khedival Agriculture Assembly. ${ }^{8}$ It was formed from elites, landowners and foreigners, and was supported widely by the Egyptian government, but the assembly was useful only for its landowner members, being far removed from the farmers and their problems. It is worth mentioning that the assembly was supported by the British because it matched their policy towards the Egyptian economy, to improve cotton cultivation for their benefit. Hussein Kamel led the assembly before his son. Among its members during this time was Lord Cromer, whose presence showed the satisfaction of the British with the assembly, and in turn encouraged landowners to join. Its main purpose was protecting the agricultural bourgeoisie, and working for its development.

The Prince had a great role in the development of this assembly. In 1918 he issued an agricultural calendar consisting of five departments including irrigation, land ownership and cotton markets. ${ }^{9}$ On 17 January 1923, the Prince started an important policy for farmers. He decided to present golden medals for the best farmers to encourage agriculture, along with a donation of 400 Egyptian pounds every year to send assembly employees abroad. ${ }^{10}$ This was an important decision, used by the Prince for the first time, and this new policy succeeded with the farmers, motivating them to do their best. This shows the Prince's intelligence, as he found the right way to improve agriculture in Egypt without using force, and he differed from his predecessors in the assembly who neglected the young farmers.

He cared a lot about cotton cultivation as a main product of Egypt. In 1926 he constructed a cotton museum in the assembly in Al Jazeera, to help farmers improve cotton cultivation, along with the publication of scientific research about cotton. He also held an Agriculture Assembly from 20 February to 20 March to provide for the farmer's needs. ${ }^{11}$ So he played a great role in the development of agriculture, and was a great supporter of the farmers. The Prince concentrated on this matter, as he well knew that it was the main point in consolidating the Egyptian economy, which would in turn lead to independence. Great Britain was not involved in his actions, and he refused all their help in this matter.

Culturally, the Prince was interested in hunting, travelling, reading and collecting artefacts. He had a large number of books related to his interests.

7. The Egyptian Agriculture Assembly was founded in 1880 under the leadership of Hedar Pasha Yakan, because of the necessity to organize agriculture in Egypt after it had declined because of the Orabi Revolt and the British occupation.

8. R. A. Hamed, Al Melkeat Al Zraeah Al Masriah wa Daworaha fi Al Mogtma Al Masry 1837-1914 [Egyptian Landowners and Their Role towards the Egyptian Society 1837-1914] (Cairo: Supreme Council of Culture, 1983), 58.

9. Al Akhbar Newspaper, May 1918, issue 963, 22.

10. Al Ahram Newspaper, issue 13951, 19 January 1923.

11. Al Moqatm Newspaper, issue 11251, 4 March 1926. 
He donated about 5,000 books to the library of Cairo University. ${ }^{12}$ Most of this collection is on geography and travel. ${ }^{13}$ His collection, together with those of many other princes, formed the nucleus of the library.

\section{His Role in Supporting Egyptian Nationalism}

During the First World War years, the Egyptians were not asked to defend their country against the Turks or Germans, but they did suffer in other ways, such as rising prices of food and other necessities of life, limitations on the highly profitable cultivation of cotton, and crowds of British troops in the Egyptian cities. So the Egyptians tried by all means to cancel the British protectorate over Egypt at the end of the war. Prince Kamal Eldin played a role in Egyptian nationalism, supporting the National movement of Egypt. The British Commission led by Milner was sent to negotiate with the Egyptians within a framework of the British protectorate. Along with another 5 princes, Prince Omar Tosoun, Prince Mohamed Ali, Prince Youssef Kamal, Prince Youssef Dawood and Prince Mansour Dawood, he issued a declaration of the Egyptian boycott of Milner's mission in 1920, announcing support for the Egyptians in their demand for complete, unconditional, immediate evacuation of the British troops from Egypt. ${ }^{14}$ The Egyptians rejected the negotiations before the evacuation. Milner sent a letter on 5 January 1920 to prince Kamal Eldin Hussein, saying "your highness, please I want to inform you that I received your letter which you sent me together with five other princes from the Mohamed Ali dynasty, and I have the honour to be Your Highness". ${ }^{15}$ Milner sent the letter to Prince Kamal Eldin only, knowing that he stood apart from the British and rejected the British presence in Egypt.

This act made him close to the Egyptians, who hated his father, as he was brought to rule by the British. They saw the Prince as completely different from his father. He sent a telegram to congratulate Saad Zaghloul on his return to Egypt after the British exiled him ${ }^{16}$, which was of course a reflection of his support for Saad in his case. He wanted to prove to him that he was with him in fighting the British presence in Egypt. The Prince was patriotic, he loved Egypt very much, and this appeared clearly from his support for the national movement in Egypt. The Prince was apart from the British, and no meetings were held between the Prince and the British.

After the 1922 February statement, he sent a letter to the Sultan on 12 March together with many other princes, in which they supported Egyptian

12. K. I. Meho and M. A. Nsouli, Libraries and Information in the Arab World. An Annotated Bibliography (Westport: Greenwood Press, 1999), 106.

13. G. B. Edwards, The Arabian War Horse to Show Horse (Pasadena: Wood and Jones Publisher, 1969), 271.

14. Al Ahram Newspaper, Jan. 1920, 3, issue 99876.

15. A. El. El Rafcy, Thawrat 1919. Tarekh Masr Al Qawme 1914 - 1921 [1919 Revolution. The History of the National Movement in Egypt 1914-1921], 4th ed. (Cairo: Dar Elmaref, 1987), 443.

16. Al Akhbar Newspaper, Apr. 1921, 10, issue 347. 
demands for the complete and unconditional evacuation, together with the appointing of a national front for discussing the British notes which were presented to the Egyptian government. ${ }^{17} \mathrm{He}$ also invited the princes to a meeting after the disabling of parliament in 1925, and they sent a note to King Fouad demanding the return of the parliamentary life. ${ }^{18}$ So he was very keen on Egypt and to achieve Egyptian independence. This means that the Prince was away from palace life, but was not away from the Egyptians or political life, as some thought, or as was described. He had a great role in supporting the Egyptians politically and economically, although he refused to be their ruler.

Prince Kamal Eldin Hussein was the only prince from the royal family who rejected appearance in the pages of the Egyptian press, and, in the case of publishing any news concerning his life and movements, he prevented donations for them. He was described by the British as a recluse ${ }^{19}$, but actually he was recluse from the British only.

\section{The Prince Exploring the Western Desert}

Prince Kamal Eldin Hussein devoted his life to exploring the desert, such that many sites in the Western Desert were given their names by the Prince. It was said that he spent about 150 thousands Egyptian pound on these expeditions. ${ }^{20}$ He started exploring the desert in 1923, and he was fond of reading about expeditions to the area. His journeys into the desert were divided into phases, the first was from 1923 to 1924, and the second was from 1925 to 1926 . There was a third expedition in 1930 but he died without completing it.

Firstly he made a journey via Bahariya and Farafra, with three caterpillar vehicles. In 1923 he reached the landmark which he called Abu Ballas (father of pots), located 240 kilometres west-southwest of Dakhla. It was named by Prince Kamal Eldin because hundreds of water pots were found around its base, and this was the first place which was named by him. ${ }^{21}$ It is a hill rather than a mountain and was used as a storage place for water. ${ }^{22}$ There is rock art in the area of Abu Ballas; it is possible that the Ancient Egyptians had water depots throughout the desert. Prince Kamal Eldin said that maybe these pots were left by Tebu tribesmen from Libya for

17. A. El. Lashin, Saad Zaghloul wa Daoreh fi Al Hayah Al Syasia [The Role of Saad Zagloul Personal on the Political Life] vol 2 (Cairo, 1975), 103.

18. M. Mohamed, ElTarekh Elsiri Li Masr mn Al Wathaeq Al Britania wa Al Amrecia[The Secret History of Egypt from The British and the American Documents] (Cairo: Dar Elmaref, 1979), 35.

19. P. Mansfield, The British in Egypt (California: Holt, Rinehart and Winston, 1972), 217.

20. Kh. El. Al Zeralkey, Qamws Al Trajem wa Al Alam, vol.5, 233.

21. Prince Kamal Eldin Hussein, La Geographie [Geography], Tome L, No.5-6 (Paris, 1928), 30.

22. P. H.E., Cox, J.L. Myres, C.Thompson, F.L Griffith, O. Wingate and R. A. Bermann, "Historic Problems of the Libyan Desert: Discussion," The Geographical Journal, 83, no.6 (June 1934): 468. 
their frequent raids into Egypt. Kamal Eldin discovered a rock painting there, of a calf being suckled by a cow. ${ }^{23}$

Then, Prince Kamal Eldin Hussein, together with Ball, ${ }^{24}$ went to the area of the Great Sand Sea. Actually, Prince Kamal Eldin went looking for Rohlfs' marker, and found it. In 1874 Khedive Ismail ordered Rohlfs to explore the Western Desert. ${ }^{25}$ Rohlfs' marker consisted of rocks piled up on top of each other and seven empty iron water tanks. He had taken over five hundred of these tanks into the desert, and they are still there at the site. The prince found the cairn exactly where it had been left in 1874, at the base of a great dune. ${ }^{26}$ In fact, he discovered that the dune was not only in the same position, but was exactly the same height as recorded by Rohlfs. Prince Kamal Eldin was not only a discoverer, he also analysed what he discovered and put theories to it. His contribution in this field was the nucleus for his followers in their excavations in the desert. For over forty years nothing in the area had changed. Prince Kamal read the message, copied it, added another of his own, in Arabic, and placed a new bottle at the cairn. Taking the original message and some scattered remnants of the former expedition, including bottles, an axe, a water skin and a basket of dates, he headed back to Cairo. ${ }^{27}$ On this journey he discovered Merga Oasis, which had rock paintings on its hills.

The journey of the Prince was actually to Uwaynat, and he discovered both Abu Ballas and the Great Sand Sea on his way to that area. Worth mentioning is that Hassanein Pasha ${ }^{28}$ was the first to discover Uwaynat in 1923, but it was left to Prince Kamal to map the peaks and springs of the mountain. Throughout his journey he fixed geographic positions and altitudes, and in this area he discovered secrets which were not discovered by Hassanein Pasha.

23. Prince Kamal Eldin Hussein, La Geographie, 31.

24. He was an important part of the geological survey of Egypt. He founded the desert survey department and served as its director. He was called as the father of the Egyptian explorations and joined Prince Kamal on his two great desert journeys.

25. For the details of this journey see G. Rohlfs, Drei Monate in der libyschen Wuste [Three Months in the Libyan Desert] (Cassel: Verlag von Theodor Fischer, 1875).

26. Prince Kamal Eldin Hussein, La Geographie, 32.

27. Comptes Rendus des Seances de l'Academie des Sciences [Reports of Science Academy Meeting], Tome 183, July-December (1926), 935.

28. Ahmed Hassanein, the first of the modern Egyptian explorers, made a remarkable journey of 2,220 miles from the port of Sollum on the Mediterranean Sea via the oasis of Kufra. It was the first recorded crossing of the Libyan Desert in modern times, and is one of the greatest desert journeys in history. 


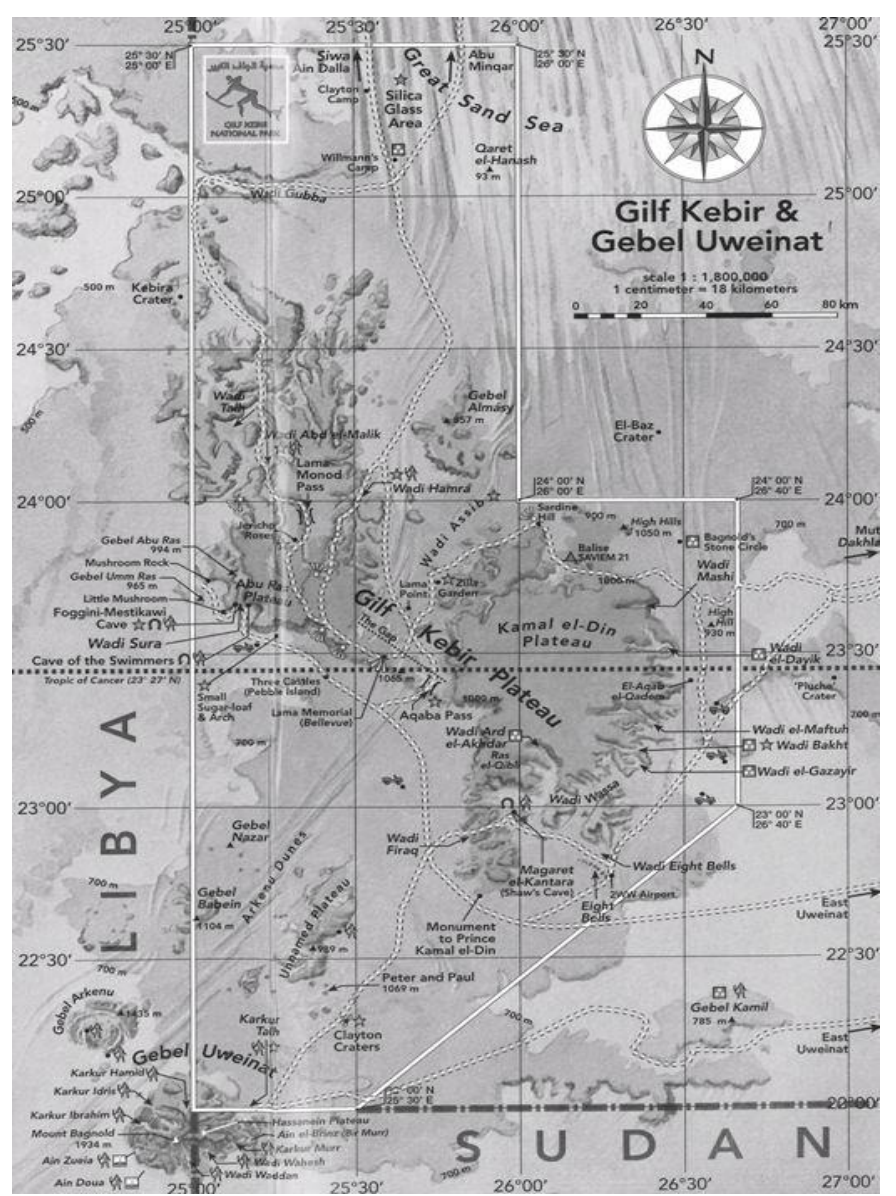

Figure 2. Map of Uwaynat and Gilf Kebir

Source: http://bit.ly/2e65zbX.

Prince Kamal arrived at Uwaynat in 1923 . About 150 people lived there under a Goran chief called Sheikh Herri, the king of Uwaynat. The chief left his home in Waidai when the French colonized it. By 1930 no one lived in the area, since a lack of rain dried up the lake. ${ }^{29}$ In the expedition he made a map of the area, and drew the springs of the mountain. In 1924, when Prince Kamal Eldin, Hassanein and Ball arrived at Nakheila, they found graffiti, including drawings of ostriches, and snakes. Most importantly there were inscriptions from the thirteenth dynasty at least, an ancient Egyptian connection close to the Darb al Arabain and Kharga Oasis. ${ }^{30}$ The Prince was keen to record all the graffiti in his notes to give an accurate description of them.

29. Prince Kamal Eldin Hussein1928, La Geographie, 33.

30.V. Betrami, "Un Avvicinamento A'LDeserto Egiziano Occidentalo" ["Approaching an Egyptian Western Desert"], Africa: Rivista Trimestrale di Studie e Documentazione de L'Instituto Italiano per L'Africa e L'Oriente, 62, no.2 (2007) Giugno, 311. 


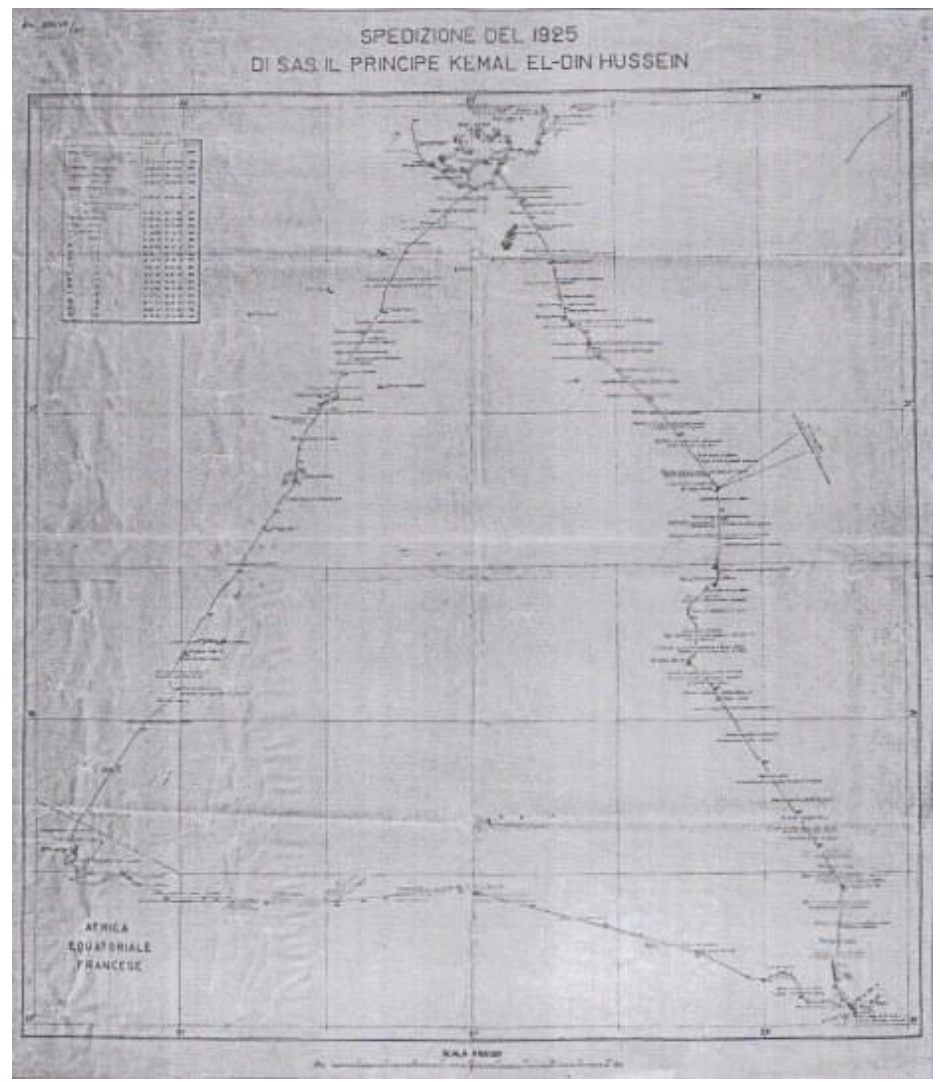

Figure 3. The Route to Uwaynat

Source: http://bit.ly/2eiQ2rd.

The Libyan Desert is very rich with rock paintings and engravings. Prince Kamal Eldin Hussein recorded many of these paintings during his excavations. In almost every valley of Gebel Uwaynat rock art exists. There are scenes of hunting, herding, home and hearth, and besides cattle other animals are a common theme, especially ostrich, giraffes, gazelles and few camels. ${ }^{31}$

31. For the artifacts found in the area see W. P. McHugh, "Some Archeological Results of the Bagnold Mond Expedition to the Gilf Kebir and Gebel Uweinat, Southern Libyan Desert," Journal of the Near Eastern Studies, 34, no.1 (January 1975): 31-62. 


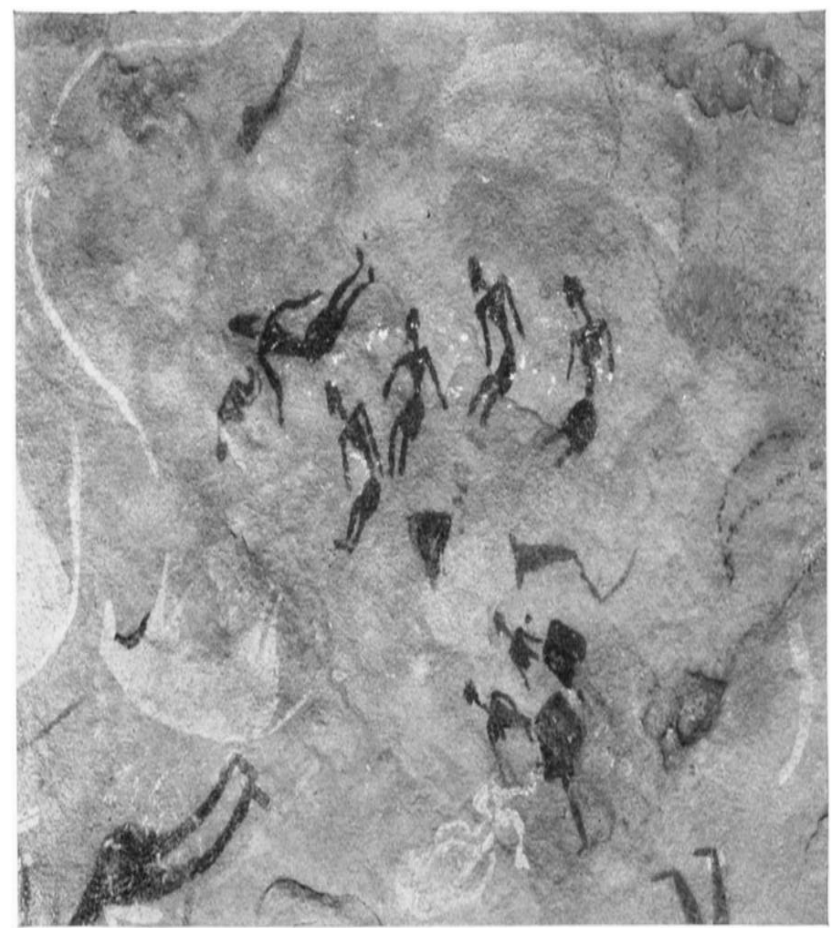

Figure 4. Uwaynat Rock Paintings

Source: R.A. Bagnold, O.H Myers, R. F. Peer, H.A. Winkler, The Geographical Journal, 93, no.4, April 1939.

This means that the area is important, not only for those who are interested in adventure in the desert or safari, but also for Egyptologists and archaeologists. The Prince was so interested in the paintings; he considered them a treasure for the explorers. From the paintings one can imagine the life style in this area in the past, and can predict what happened in the area, so he cared greatly about copying them.

The following year, the prince continued his work in the south-western corner of Egypt. He left Cairo on 26 December 1925, reaching Dakhla oasis on 29 December. His first rest was at Abu Ballas on 1 January 1926, and he stayed there till the $6^{\text {th }}$ of January. Then he moved to Uwaynat, reaching there on the $13^{\text {th }}$ of January. ${ }^{32}$

\section{The Discovery of Gilf Kebir}

At the end of the first phase the Prince returned to Cairo, on 9 March 1925. He continued making expeditions into the Western Desert, and the second phase was to explore the middle part of the Libyan Desert, the purpose being to continue exploring the area of Uwaynat. This phase of the expedition consisted of eighteen members, a geologist, a topographer, engineers, a cook, a person called Abo Omar Abdulla who knew the area well, and a doctor. Two cars carried the equipment, food and baggage.

32. Prince Kamal Eldin Hussein1928, La Geographie, 33. 
In 1926 he discovered a grand plateau that emerged from the sand named Gilf Kebir. It was the Prince who gave the area this name on his way to Uwaynat; it was the highest point on the cliffs. ${ }^{33}$ Its steep-sided cliffs stimulated its discoverer, to call it El-Gilf (the rude), El Kebir (large) ) $^{34}$ plateau, as it seemed to rebuff him while he was attempting to ascend it. The Gilf Kebir is a sandstone plateau 93 miles north of Gebel Uwaynat covering over 7,770 square kilometres. Dozens of valleys extend into the desert around its perimeter. These valleys were formed by water erosion in a wetter phase. The high southern part of the plateau was sighted for the first time in 1925 by the Prince on his way from Kharga to Uwaynat, but its size was not realized until 28 January 1926, when the Prince's expedition to Sarra passed close by and fixed the eastern escarpment of the plateau ${ }^{35}$. It was the most important discovery for the Prince, and from this time the name of the Prince became famous among geographers and desert specialists.

In fact, the Prince is a famous figure for those interested in geography and adventure in the desert. There is even a page celebrating the Prince's travels to the Western Desert on Facebook. ${ }^{36}$ This is a reflection of the importance of his expeditions to this area, which deserved interest because of the life he spent in the desert. Under the auspices of the Ministry of Tourism, an historical event commemorating 80 years since Prince Kamal Eldin's expedition to Gilf Kebir took place from 15 to 27 March 2013. ${ }^{37}$ This expedition's aim was to commemorate the anniversary of the memorial plaque of Prince Kamal Eldin Hussein the discoverer of Gilf Kebir plateau in the Western Desert of Egypt.

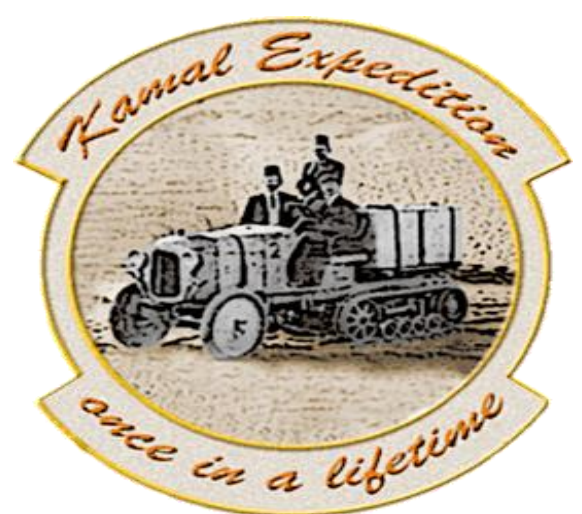

Figure 5. The Slogan of the Egyptian Tourism Ministry Expedition Source: http://bit.ly/KLhY5v.

33. H.W.G.J. Penderel, "The Gilf Kebir," The Geographical Journal, 83, no.6 (June 1934): 451.

34. Prince Kamal Eldin Hussein, La Geographie, 33.

35. F.J.R. Rodd. "A Reconnaissance of the Gilf Kebir by the Late sir Robert Clayton East Clayton," The Geographical Journal, 81, no.3 (1933): 254.

36. Kamal Expedition: In the Footsteps of the Prince, http://bit.ly/2eeii1K.

37. Egypt Travel, http://bit.ly/2ezAe1c. 
A group of desert enthusiasts and members of the Ministry of Tourism gathered to commemorate the expeditions of Prince Kamal Eldin Hussein at the Cairo Opera House, and to promote a new trip called the Kamal Expedition, a journey to the Western Desert. Dorothe Rieche, one of the organizers of the Kamal expedition said, "The idea is to boost ecotourism". ${ }^{38}$ The expedition lasted twelve days, tracing the steps of Prince Kamal Eldin's journey. Egypt was facing difficult times and they wanted to remind the people that Egypt has different tourist faces, the desert being one of them.

Since the discovery of this remote area by Prince Kamal Eldin Hussein in 1925, a number of expeditions have been sent there, but the most important expeditions to the area were those carried out by the Prince himself. There were many expeditions to the area funded by the Prince, although he was not among the members. ${ }^{39} \mathrm{He}$ helped them because of his interest in the matter, and not to glorify his name. In 1930 a group of scientists, included Beadnell, ${ }^{40}$ Ball, Bagnold and Clayton ${ }^{41}$, ventured into the heart of the Western Desert to complete the excavations started by the Prince. ${ }^{42}$ Also Al Ahram newspaper sent an expedition to Uwaynat in 1934, and they made a large collection of drawings and photographs of the rock art paintings there. Hans Winkler ${ }^{43}$ after hearing about the rock art of the area went to Uwaynat in 1938 and did extensive work on the rock, especially in the south of Uwaynat. ${ }^{44}$

Another important matter here is that Prince Kamal Eldin pioneered the use of motor vehicles for desert exploration. His 1925 Expedition consisted of eight Citroen Kegresses and a Ford Torpedo. The Prince himself drove a Citroen - the leading car. The cars were loaded, on the $29^{\text {th }}$ of December in 1924, onto the railroad leaving Cairo all the way to the Kharga Oasis. ${ }^{45}$ This was a great contribution by the Prince, from that moment cars were used in the desert.

38. L. Rios, "The Kamal Expedition seeks to boost Egypt's ecotourism," The Cairo Post, last modified Nov. 19, 2013, http://bit.ly/2e6Kccj.

39. A. Siliotti, Gilf Kebir National Park (Verona, Italy: Geodia, 2009), 16- 17.

40. He did not stay long in Egypt but his work is among the best of the desert survey. He published a number of books in addition to the survey work.

41. He had a short career in the Libyan Desert. Educated at Dartmouth he was with the royal navy, serving as a pilot. He died two months after returning from the Gilf Kebir in September 1933.

42. Annals of the Geological Survey of Egypt, vol.13, Geological Survey of Egypt and Mining Authority, 1983, 123.

43. Hans Winkler was the best of those who wrote about the rock art in the Western Desert. For these rock paintings see, J- L le Quellec and D. Hugge, "Rock Art Research in Egypt 2000-2004," in Rock Art Studies News of the World III, ed. P. Bahn, N. Franklin and M. Strecker (Oxford: Oxbow Books, 2008), 89.

44. R.A. Bagnold, O.H. Myers, R.F. Peel and H.A. Winkler, "An Expedition to the Gilf Kebir and Uweinat 1938," The Geographical Journal, 93, no.4 (April 1939): 281.

45. Prince Kamal Eldin Hussein, La Geographie, 34. 


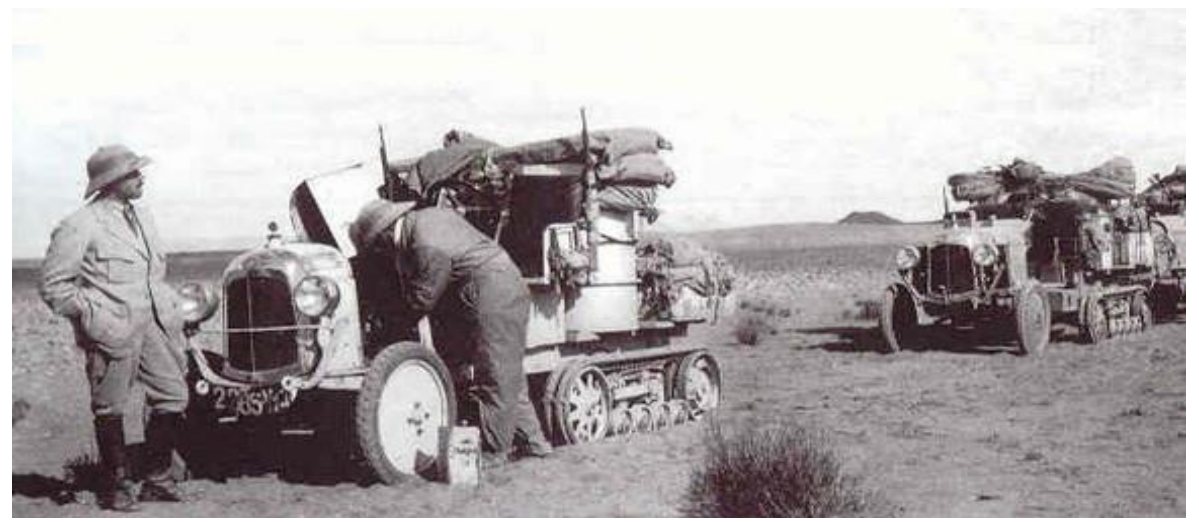

Figure 6. The Cars in the Desert

Source: http://bit.ly/2eNeDUw.

There is a monument to Prince Kamal Eldin in the Western Desert. This monument was written in Arabic on the side of a wadi to commemorate the exploits of the Prince. It was placed in the Wadi Faragh by Almasy. ${ }^{46}$ Ahmed Hassanein introduced Almasy to the Prince, following Almasy's 1932 expedition with Clayton to the Western Gilf. The Prince offered to finance Almasy's explorations to reach the mythical Zarzura oasis. However, just a few months later the Prince died, and Almasy was left without a financer. He found support for a further expedition in 1933, in which he erected a marble tablet at the southern tip of the Gilf Kebir in honour of the Prince. It was a reflection of the importance of Prince Kamal Eldin's Desert excavations, which were appreciated by other explorers, that this monument was added to the area not by the Prince himself, but by these explorers.

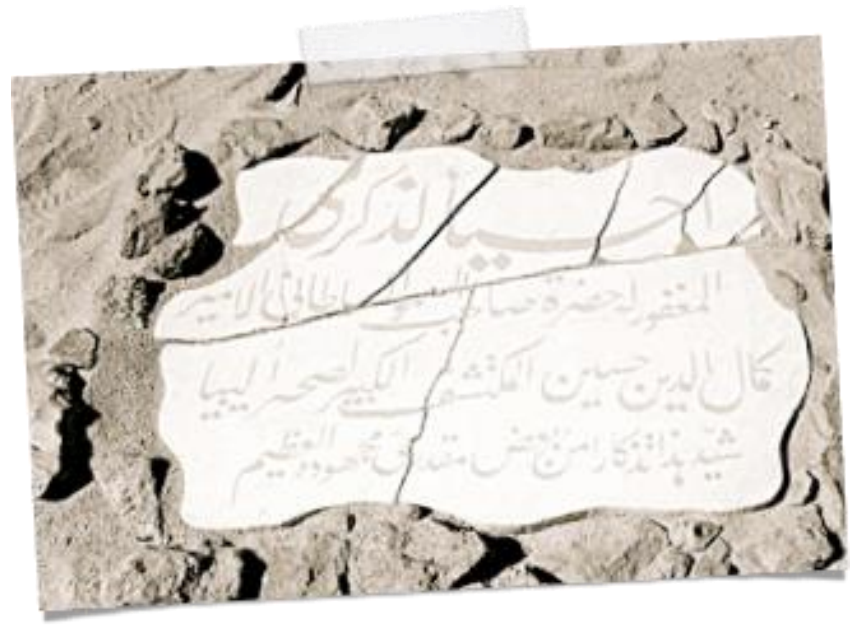

Figure 7. The plaque of Prince Kamal Eldin Source: http://bit.ly/KLhY5v.

46. Ladislaus Edward de Almasy, a Hungarian count, did a little of everything in the western desert. He was fearless, speaking six languages; he first came to Egypt as a representative of the Austrian Steyr off-road car. Between 1923 and 1938, first under the leadership of prince Kamal Eldin he crisscrossed the dangerous terrain of the Libyan Desert by airplane, seeking to solve many of its mysteries. In 1931 he was the first to find his way to the top of the Gilf Kebir via a gap now called Aqaba near wadi Firaq 
Prince Kamal Eldin also supervised the making of a map of the Libyan Desert in Paris, and in 1928 was awarded the Gold Medal of the Geographical Society of France for his work in the Western Desert.

\section{The Rejection of the Throne by the Prince}

The Prince was titled heir presumptive, but he refused the rule and left it for his uncle King Fouad. ${ }^{47}$ He published his wavier of the throne in the Egyptian newspapers without giving reasons for this act; he just said that he could serve the country more than as a ruler, so he left this right to another. ${ }^{48}$

This matter was a secret in modern Egyptian history - how the throne, which saw many struggles between members of the royal family, was rejected by him. There were two opinions concerning this matter. The first opinion was that he was interested in adventure and exploring the desert, so he rejected the rule because he did not want anything occupying him and isolating him from his favourite hobby. ${ }^{49}$ The prince started exploring the desert in 1923, but he had refused the throne in 1917. There were six years between the two dates. It is not logical to think that he refused to rule because of his expectation that he would discover the desert; also he could explore the desert as ruler of Egypt. So it is unbelievable that he refused to rule because of his excavations, or because of his hobby. Another member of the royal family, Prince Mohamed Ali Tewfik, was also interested in travelling and excavation, and his only dream was to be $\operatorname{ruler}^{50}$. His excavations did not prevent his dream.

The second opinion is that he rejected the rule under the British occupation and their presence in Egypt. Great Britain declared its protectorate over Egypt in 1914, and the British isolated Khedive Abbas Hilmi II and appointed Sultan Hussein Kamel the father of the Prince instead. This act was widely rejected by the Egyptians. They considered the Sultan to be the hand of Great Britain. In one of his speeches he said "the behaviours of officers and men since the beginning of the occupation had been perfect; there has been no swaggering and no sabre-rattling in their relations with the inhabitants of the country". ${ }^{51}$ This declaration is a reflection of his policy towards the British. Because of this policy he faced two murder trials; the first was in Cairo on 8 April 1915, and the second was

47. L. Lloyd, Egypt since Cromer, vol. II (London: Macmillan and Company, 1933), 258.

48. Al Ahaly Newspaper. Oct. 1917, 10. issue 7987.

49. A. Siliotti, Gilf Kebir National Park, 16.

50. E. F. Yehia, "Prince Mohamed Ali Tewfik after the July Revolution and the Journey of Searching for the Lost," Journal of the American Research Center in Egypt, 51(2015): 197.

51. E.P. B. Weigall, A History of Events in Egypt from 1798 to 1914 (London: Biblio Bazaar, 1915), 334. 
in Alexandria on 9 July $1915 .^{52}$ There were just four months between the two trials, which meant that his presence was rejected by the Egyptians.

The Prince was aware of the Egyptian rejection of his father's presence as he was brought to the throne by the British. Also his wife, Princess Nimet Allah Tewfik did not recognize the legitimacy of the dethronement of her brother Abass Hilmi II. From what was mentioned about the role of the Prince in the national movement, it appears clearly that he had a great role in supporting it. This consolidates the opinion which seems to be the closest to the truth - the Prince did not rule, because he rejected to rule under the British protectorate.

In 1932, at the age of fifty eight, and as a result of a leg amputation complication, the prince died in France. The Prince became ill after a journey and went to the Anglo American hospital in Cairo. Then he left the hospital and travelled to France for recreation, but died a few months after his departure. The only desire of the Prince was to be buried in the Muqatam hills in a vault constructed for him. He did not leave any commandment concerning his palace in Cairo, which was sold by Princess Nimet Allah in 1938 to the Egyptian Ministry of Foreign Affairs.

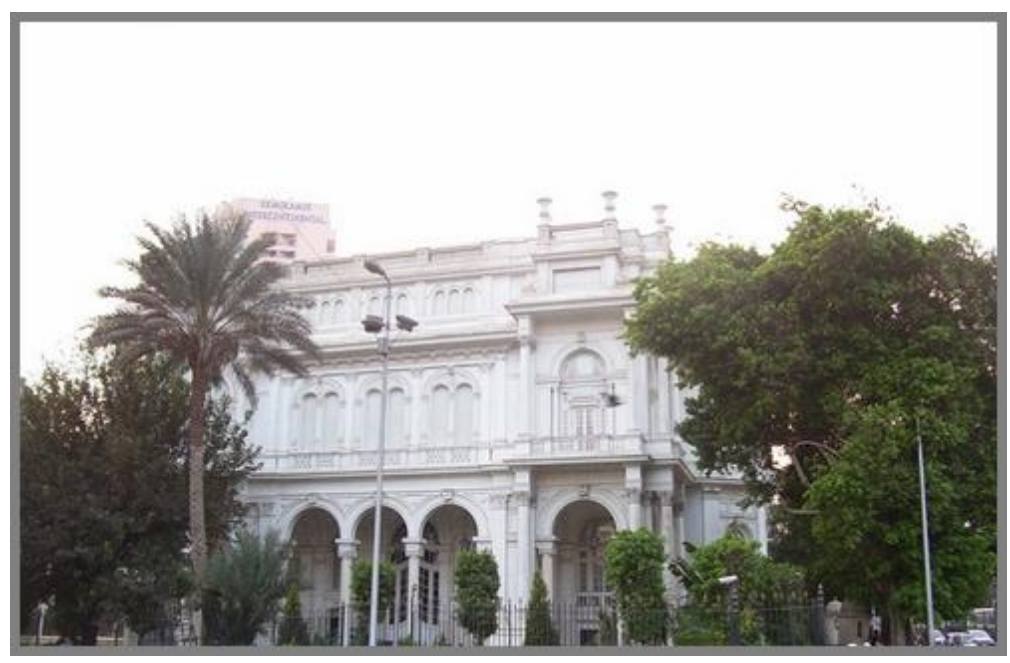

Figure 8. The Palace of the Prince

Source: http://bit.ly/2eECIhs.

\section{Conclusion}

Prince Kamal Eldin Hussein was an important member of the royal family, famous for his charity. Although he lived away from palace life, he was not away from the Egyptians. He played a great role in the development of the Agriculture Assembly, and was the first to encourage young farmers with prizes and golden medals to improve agriculture. He supported the national movement in Egypt under the British occupation. He had a great

52. A. El. El Rafcy, Thawrat 1919. Tarekh Masr Al Qawmy from 1914 to 1921 [1919 Revolution and the History of the National Movement in Egypt 1914-1921], 39. 
role in exploring the Western Desert; many sites in the Western Desert still bear the names given to them by the Prince. The most important discovery for the Prince was the Gilf Kebir plateau, which was commemorated by the Egyptian Tourism Ministry. The prince funded many famous discoveries there, such as his funding of Almasy. The Prince is commemorated in a plaque bearing his name, added by Almasy, in the Western Desert. It seems that the Prince refused to rule under the British presence in Egypt.

\section{Bibliography}

Al AkhbarNewspaper. May 1918, 22. issue 963.

Al Akhbar Newspaper. Apr. 1921, 10. issue 347.

Al Ahaly Newspaper. Oct. 1917, 10. issue 7987.

Al Ahram Newspaper. January 1923, 19. issue 13951.

Al Ahram Newspaper. Jan. 1920, 3. issue 99876, 3.

Almswar Newspaper. Feb. 1933. issue 409, 3.

Al Moaed Newspaper. Feb. 1915, issue 9876, 27.

Al Moqatm newspaper 1926, issue 11251, 4 March 1926.

Al Zeralkey, Kh.El. Qamws Al Trajem wa Al Alam [Dictionary of the Famous C.V.s], vol.5, $5^{\text {th }}$ ed. Beirut: Dar Elealm Llmalaeen, 2002.

Annals of the Geological Survey of Egypt, vol.13. Geological Survey of Egypt and Mining Authority, 1983.

Bagnold, R.A., O.H. Myers, R.F. Peel and H.A. Winkler."An Expedition to the Gilf Kebir and Uweinat 1938." The Geographical Journal, 93, no.4 ( April 1939).

Betrami, V. "Un Avvicinamento A'LDeserto Egiziano Occidentalo" ["Approaching an Egyptian Western Desert"]. Africa: Rivista Trimestrale di Studie e Documentazione de L'Instituto Italiano per L'Africa e L'Oriente, 62, no.2 (2007) Giugno.

Comptes Rendus des Seances de l'Academie des Sciences [Reports of Science Academy Meeting], Tome 183, July-December (1926), Paris.

Cox P. H.E., J.L. Myres, C. Thompson, F.L. Griffith, O. Wingate and R. A. Bermann. "Historic Problems of the Libyan Desert: Discussion." The Geographical Journal, 83, no.6 (June 1934).

Edwards G. B. The Arabian War Horse to Show Horse. Pasadena: Wood and Jones Publisher, 1969.

El Rafcy A. El. Thawrat 1919. Tarekh Masr Al Qawme 1914 - 1921 [1919 Revolution and the History of the National Movement in Egypt 1914-1921], $4^{\text {th }}$ ed. Cairo: Dar Elmaref, 1987.

Egypt Travel. http://bit.ly/2eMACth.

Fahmi, Z. Safwat Alaser fi Tareikh wa Rswoom Mashaheer Rejal Masr [The Chosen from the Famous from Egypt]. Cairo: Hendawi Institution for Education and Culture, 2013.

Rodd, F.J.R. "A Reconnaissance of the Gilf Kebir by the Late sir Robert Clayton East Clayton." The Geographical Journal, 81, no.3 (1933).

Hamed, R. A. Al Melkeat Al Zraeah Al Masriah wa Daworaha fi Al Mogtma Al Masry1837-1914 [Egyptian Landowners and their Role Towards the Egyptian Society]. Cairo: Supreme Council of Culture, 1983.

Lashin, A. El. Saad Zaghloul wa Daoreh fi Al Hayah Al Syasia [Saad Zaghloul and his Role Towards the Egyptian Society], vol 2. Cairo, 1975. 
le Quellec, J- L. and D. Hugge. "Rock Art Research in Egypt 2000-2004." In Rock Art Studies News of the World III. Edited by P. Bahn, N. Franklin and M. Strecker. Oxford: Oxbow Books, 2008.

Lloyd, L. Egypt since Cromer, vol. II. London: Macmillan and Company, limited, 1933.

Mansfield, P. The British in Egypt. California: Holt, Rienhart and Winston, 1972.

McHugh W. P. "Some Archeological Results of the Bagnold Mond Expedition to the Gilf Kebir and Gebel Uweinat, Southern Libyan Desert." Journal of the Near Eastern Studies, 34, no.1 (January 1975): 31-62.

Meho K. I. and Nsouli M. A. Libraries and Information in the Arab World. An Annotated Bibliography. Westport: Greenwood Press, 1999.

Mohamed, M. ElTarekh Elsiri Li Masr mn Al Wathaeq Al Britania wa Al Amrecia [The Secret History of Egypt from the British and the American Documents]. Cairo: Dar, Elmaref, 1979.

Penderel, H.W.G.J. "The Gilf Kebir." The Geographical Journal, 83, no.6 (June 1934).

Prince Kamal Eldin Hussein. La Geographie [Geography]. Tome L, No.5-6, Paris, 1928.

Ramadan A. E. Mozkrat Saad Zaghloul [Saad Zaghloul personal Notes], vol 6, from 13 September 1916 to 15 November 1917. Cairo: Marcaz Wathaeq waTarekh Masr El Moaser, 1993.

Rios, L. "The Kamal Expedition seeks to boost Egypt's ecotourism." The Cairo Post. Last modified Nov. 19, 2013. http://bit.ly/2e6Kccj.

Rohlfs, G. Drei Monate in der libyschen Wuste [Three Months in the Libyan Desert]. Cassel: Verlag von Theodor Fischer, 1875.

Rosten, D. B. The Last Cheetah of Egypt: A Narrative History of Egyptian Royalty from 1805 to 1953. Bloomington: i Universe Press, 2015.

Siliotti, A. Gilf Kebir National Park. Verona, Italy: Geodia, 2009.

Weigall E.P. B. A History of Events in Egypt from 1798 to 1914. London: BiblioBazaar, 1915.

Yehia E. F., "Prince Mohamed Ali Tewfik after the July Revolution and the Journey of Searching for the Lost." Journal of the American Research Center in Egypt, 51(2015). 